\title{
Supraglottic Carcinoma
}

National Cancer Institute

\section{Source}

National Cancer Institute. Supraglottic Carcinoma. NCI Thesaurus. Code C5973.

A carcinoma of the larynx that arises from the supraglottic area. 